\title{
Invocation for Religious Leaders for McGovern
}

June 1, 1972

As a reflection of his own strong political proclivities, Rabbi Beerman delivered an invocation at a gathering of religious leaders to hear the Democratic candidate for president, Senator George McGovern. He held McGovern in high regard, as an intelligent and moral man-in many respects, the opposite of how he regarded President Richard M. Nixon. The invocation repeats, in large measure, the language of his presentation at the UCLA teach-in on Vietnam in 1966, with a slight change to take note of the passage of time-and the continuation of the Cold War.

"It was the best of times; it was the worst of times. It was the age of wisdom; it was the age of foolishness. It was the season of Light; it was the season of Darkness, it was the spring of hope; it was the winter of despair. We had everything before us. We had nothing before us. We were all going direct to Heaven; we were all going direct the other way..."

Those are the familiar words with which Charles Dickens opened his novel $A$ Tale of Two Cities. The paradoxes to which he addressed himself unfortunately persist in our times, and to live in the midst of such paradoxes is the particular challenge and burden of our generation.

Forces of change beyond the control of even the best men are pushing aside the remaining ramparts of the old certainties, those truths that once sheltered and comforted us. Peace is cracked in a hundred shivers. The air of the Cold War has momentarily become warmer, but it still chills the night. In America we look outward and the world envies or despises or distrusts us. We look inward and we are plagued by the rising tide of the poor, the urban hopeless, the massive and still unresolved protest of Blacks, Chicanos, women and other oppressed groups. 
It is emotionally wearing to be living at the end of one era and the beginning of another, vaguely knowing that something is coming to an end, and something is crouching toward Bethlehem waiting to be born.

For almost twenty-five years, we have been living through a time called a "Cold War." For twenty-five years, our government has been acting on the assumption that communism was on the march for the conquest of the world and that it was the manifest destiny of the United States to save the world from suffering this fate. In the pursuit of this mirage, this myth, we have engaged in the most fantastic kind of international adventurism. In the process, our hands have been covered with blood. We have become as brutalized as those we call our enemies, as we have seen how some of our best young men have been able to torture, kill, and burn combatants and non-combatants alike.

For twenty-five years, we have sacrificed upon the altar of war and its preparation the greatest gifts of this nation, the gifts of mind and technique and sensitivity, and in so doing we have demonstrated a total contempt for man. This same era has given us a glimpse of what man's knowledge could have done for us, but we have made no serious effort to bring this golden age into being. Compassion has not been a full-time occupation for any of us. Our ingenuity, our resources, have literally been swallowed up by our consuming endeavor to stalk the enemy. Our laboratories, our universities, our research centers have found themselves dedicated to the same fanatical pursuits.

For twenty-five years, the angel of death has hovered over our civilization, fending off any serious endeavor to re-cultivate the waste places or to make a serious assault upon the problems of anguish.

The result of all this cannot adequately be measured. You and I know it in the form of greater frustration and estrangement, a sense of impotence. The poor know it in the form of even greater poverty.

Such an age as ours may very well bring tourists to the moon but it will hardly make a contribution to the human spirit. For in such an age, the artist, the thoughtful man, the man of wisdom, the student, even the man of religion is no longer able to see the healing role the responsible use of his talents would demand of him ...

\section{COMMENTARY BY THE REVEREND J. EDWIN BACON}

We were reeling in 1971-those of us in America's "peace and justice community." We had recently been struck by a season of assassinations-of President Kennedy, of Dr. King, and of Bobby Kennedy. And then there was the protracted immoral war in Vietnam, perverting the nation's leaders to justify the "fog of war." Our nation sacrificed on the altar of war innocent Vietnamese lives, American youth and technology, all the while draining limited resources from those who were poor and hungry to feed war's voracious appetite. When Leonard Beerman offered his 
invocation, a hopeful moment had arisen in George McGovern's clear and courageous voice, naming the immorality of the war in Vietnam and holding out a promise for a different national and global narrative.

That narrative was one of moral reckoning and self-critique about the sacrilege of what we were doing in the name of democracy. Leonard knew the paradox of the moment as he invoked the God of justice and peace in lyrical language and with a clear moral imperative, echoing not only the Torah and the Prophets, but also Dickens, Yeats, and Didion. Leonard never shied away from moral indictment and outrage, but always delivered them with words of love and hope.

Because of Leonard, we who heard his words and were inspired by his actions felt more deeply our discomfiting yet exhilarating mission: to join the resistance, to make a contribution to the human spirit, and to play our role in the neverending enterprise of healing. 